\title{
PENGARUH PEMBERIAN PUPUK KANDANG KOTORAN AYAM DAN PUPUK NPK MUTIARA YARAMILA TERHADAP PERTUMBUHAN DAN HASIL TANAMAN TERUNG (Solanum melongena L.) PADA TANAH BERPASIR
}

\author{
MOHAMMAD HERTOS \\ Dosen Program Studi Agroteknologi Fakultas Pertanian dan Kehutanan \\ Universitas Muhammadiyah Palangkaraya
}

\begin{abstract}
The purpose of this research was to find Chiken Manure and NPK Mutiara Yaramila Fertilizer on the growth and yield eggplant (Solanum melongena L.) in sandy soil. The reaserch were arranged in Completely Randomized Design with two factors and three duplications. The first factor was to find chiken manure $(K)$ on the three levels : 20 ton/ha $\left(K_{1}\right), 30$ ton/ha $\left(K_{2}\right)$ and 40 ton/ha $\left(K_{3}\right)$, the second factor was NPK Mutiara Yaramila Fertilizer (Y) on the three level : $200 \mathrm{~kg} / \mathrm{ha}\left(Y_{1}\right), 300 \mathrm{~kg} / \mathrm{ha}\left(Y_{2}\right)$ and $400 \mathrm{~kg} / \mathrm{ha}\left(Y_{3}\right)$.

The results show the experiment treatments of chiken manure and NPK Mutiara Yaramila Fertilizer was significantly on the parameters : plant high, number of leaf, number of productive branches, number of fruit and weight of fruit.

The highest yeild to parameters of plant high in old 2, 4 and 6 MST $(25,30 \mathrm{~cm}, 36,37 \mathrm{~cm}$ and 60,83 $\mathrm{cm}$ ) number of leaf in old 2, 4 and 6 MST (8,67 sheet, 11,00 sheet and 23,33 sheet), number of productive branches (8,67 branches), number of fruit (4,33 fruits) and weigth of fruit $(417,23 \mathrm{~g})$, obtainable on the treatments to find chiken manure as big as 40 ton/ha and NPK Mutiara Yaramila Fertilizer as big as 300 $\mathrm{kg} / \mathrm{ha}$.
\end{abstract}

Keywords : chiken manure, NPK Mutiara Yaramila Fertilizer, eggplant, sandy soil

\section{ABSTRAK}

Penelitian ini bertujuan untuk mengetahui pengaruh interaksi pemberian pupuk kandang kotoran ayam dan pupuk NPK Mutiara Yaramila terhadap pertumbuhan dan hasil tanaman terung pada tanah berpasir.

Penelitian ini merupakan percobaan faktorial dengan dua faktor yang disusun berdasarkan Rancangan Acak Lengkap (RAL) dengan tiga ulangan. Faktor I : Pemberian Pupuk Kandang Kotoran Ayam (K) yang terdiri dari tiga taraf, yaitu : $K_{1}=20$ ton/ha (160 gram/polybag), $K_{2}=30$ ton/ha (240 gram/polybag) dan $\mathrm{K}_{3}=40$ ton/ha (320 gram/polybag). Faktor II : Pemberian Pupuk NPK Mutiara Yaramila (Y) yang terdiri dari tiga taraf, yaitu : $Y_{1}=200 \mathrm{~kg} / \mathrm{ha}(1,6 \mathrm{gram} /$ polybag $), Y_{2}=300 \mathrm{~kg} / \mathrm{ha}(2,4 \mathrm{gram} /$ polybag $)$ dan $Y_{3}=400$ $\mathrm{kg} / \mathrm{ha}$ (3,2 gram/polybag).

Hasil penelitian yang diperoleh menunjukkan bahwa perlakuan interaksi pemberian Pupuk Kandang Kotoran Ayam dan Pupuk NPK Mutiara Yaramila berpengaruh sangat nyata terhadap parameter tinggi tanaman, jumlah daun, jumlah cabang produktif, jumlah buah per tanaman dan berat buah per tanaman. Hasil tertinggi untuk parameter tinggi tanaman umur 2, 4 dan 6 MST $(25,30 \mathrm{~cm}, 36,37 \mathrm{~cm}$, dan $60,83 \mathrm{~cm})$, jumlah daun umur 2, 4 dan 6 MST (8,67 helai, 11,00 helai dan 23,33 helai), jumlah cabang produktif $(8,67$ cabang), jumlah buah per tanaman (4,33 buah) dan berat buah per tanaman (417,23 gram) diperoleh pada perlakuan interaksi pemberian Pupuk Kandang Kotoran Ayam dengan dosis 40 ton/ha dan Pupuk NPK Mutiara Yaramila dengan dosis $300 \mathrm{~kg} / \mathrm{ha}$

Kata kunci : pupuk kandang kotoran ayam, pupuk NPK Mutiara Yaramila, terung, tanah berpasir

\section{PENDAHULUAN}

Tanaman terong di Indonesia merupakan sayuran yang cukup dikenal dan digemari oleh seluruh lapisan masyarakat. Buah terong yang masih muda selain enak untuk dijadikan berbagai sayuran dan lalapan, juga mengandung gizi yang cukup tinggi dengan komposisi yang lengkap. 
Kandungan gizi dalam tiap 100 gram buah terong segar mengandung vitamin A $30,00 \mathrm{mg} / \mathrm{SI}$, vitamin $B \quad 0,40 \mathrm{mg}$, vitamin C $5,00 \mathrm{mg}$, protein 1,10 gram, karbohidrat 5,50 gram, fosfor 37,00 $\mathrm{mg}$, kalsium $15,00 \mathrm{mg}$, zat besi $0,40 \mathrm{mg}$ dan air 92,70 gram (Rukmana, 2000).

Luas areal penanaman terong di Kalimantan Tengah tahun 1998 adalah 1.705 ha dengan rata-rata hasil sebesar 0,34 ton/ha, sedangkan pada tahun 1999 adalah seluas 6.992 ha dengan rata-rata hasil 1,6 ton/ha (Anonim, 2000). Apabila dibandingkan dengan produksi nasional yang rata-ratanya mencapai 3,4 ton/ha, maka hasil terong di Kalimantan Tengah tergolong masih rendah.

Rendahnya produksi di Kalimantan Tengah, kemungkinan disebabkan oleh kondisi tanah yang produktivitasnya rendah (berupa tanah berpasir), adanya teknik budidaya yang belum sepenuhnya dikuasai seperti faktor lingkungan.

Tanah berpasir pada umumnya mempunyai porositas yang tinggi sehingga daya untuk menahan air rendah serta ketersediaan unsur hara rendah, maka untuk mengatasi hal tersebut perlu ditambahkan bahan-bahan organik seperti pupuk kandang kotoran ayam, untuk meningkatkan kemampuan tanah menahan air sekaligus menambah unsur hara. Disamping itu untuk meningkan unsur hara makro di dalam tanah maka perlu ditambahkan pupuk NPK Mutiara Yaramila yang mengandung tiga unsur sekaligus, yaitu unsur Nitrogen (N), Phosfat (P) dan Kalium (K) (Lingga dan Marsono, 2001).

Penelitian ini bertujuan untuk mengetahui pengaruh interaksi pemberian pupuk kandang kotoran ayam dan pupuk NPK Mutiara Yaramila dan untuk mengetahui pengaruh faktor tunggal pemberian pupuk kandang kotoran ayam dan pupuk NPK Mutiara Yaramila terhadap pertumbuhan dan hasil tanaman terung pada tanah berpasir.

\section{METODOLOGI}

Penelitian ini dilaksanakan pada bulan November 2014 - Februari 2015. Penelitian dalam rumah plastik ini bertempat di Jl. Cilik Riwut Km. 9 Kota Palangka Raya.

Bahan-bahan yang digunakan dalam penelitian ini yaitu benih terong varietas Mustang F1, pupuk kandang kotoran ayam, pupuk NPK Yaramila (sebagai perlakuan) dan tanah berpasir.

Sedangkan alat-alat yang digunakan dalam penelitian ini adalah kayu, papan, cangkul, gergaji, palu, polybag, ember, gayung, meteran, timbangan, plastik putih transparan, kain kasa, kamera dan alat tulis.

Penelitian ini merupakan percobaan faktorial dengan dua faktor yang disusun berdasarkan Rancangan Acak Lengkap (RAL) dengan 3 ulangan.

Faktor I : pemberian pupuk kandang kotoran ayam $(\mathrm{K})$ yang terdiri dari 3 taraf, yaitu :

$\mathrm{K}_{1}=20$ ton/ha (160 gram/polybag)

$\mathrm{K}_{2}=30$ ton/ha (240 gram/polybag)

$\mathrm{K}_{3}=40$ ton/ha (320 gram/polybag)

Faktor II : pemberian pupuk NPK Mutiara Yaramila $(Y)$ yang terdiri dari 3 taraf, yaitu:

$Y_{1}=200 \mathrm{~kg} / \mathrm{ha}$ (1,6 gram/polybag)

$\mathrm{Y}_{2}=300 \mathrm{~kg} / \mathrm{ha}(2,4 \mathrm{gram} /$ polybag $)$

$\mathrm{Y}_{3}=400 \mathrm{~kg} / \mathrm{ha}$ (3,2 gram/polybag)

Dari kedua perlakuan tersebut di atas, setelah dikombinasikan diperoleh 9 kombinasi perlakuan seperti pada Tabel 1. 
Tabel 1. Kombinasi perlakuan

\begin{tabular}{|c|c|c|c|}
\hline \multirow{2}{*}{$\begin{array}{c}\text { Pupuk } \\
\text { Kandang } \\
\text { (K) }\end{array}$} & \multicolumn{3}{|c|}{ Pupuk NPK Mutiara Yaramila (Y) } \\
\cline { 2 - 4 } & $\mathrm{Y}_{1}$ & $\mathrm{Y}_{\mathbf{2}}$ & $\mathrm{Y}_{3}$ \\
\hline $\mathrm{K}_{1}$ & $\mathrm{~K}_{1} \mathrm{Y}_{1}$ & $\mathrm{~K}_{1} \mathrm{Y}_{2}$ & $\mathrm{~K}_{1} \mathrm{Y}_{3}$ \\
$\mathrm{~K}_{2}$ & $\mathrm{~K}_{2} \mathrm{Y}_{1}$ & $\mathrm{~K}_{2} \mathrm{Y}_{2}$ & $\mathrm{~K}_{2} \mathrm{Y}_{3}$ \\
$\mathrm{~K}_{3}$ & $\mathrm{~K}_{3} \mathrm{Y}_{1}$ & $\mathrm{~K}_{3} \mathrm{Y}_{2}$ & $\mathrm{~K}_{3} \mathrm{Y}_{3}$ \\
\hline
\end{tabular}

\section{HASIL DAN PEMBAHASAN}

\section{Hasil Penelitian}

\section{Tinggi Tanaman}

Hasil analisis ragam menunjukkan bahwa interaksi perlakuan pemberian pupuk kandang kotoran ayam dan pupuk NPK Mutiara Yaramila berpengaruh sangat nyata terhadap parameter tinggi tanaman umur 2, 4 dan 6 MST. Hasil uji beda rata-rata tinggi tanaman disajikan pada Tabel 2

Tabel 2. Hasil uji beda rata-rata Tinggi Tanaman Terong umur 2, 4, dan 6 MST.

\begin{tabular}{|c|c|c|c|}
\hline \multirow{2}{*}{ Perlakuan } & \multicolumn{3}{|c|}{ Tinggi Tanaman } \\
\cline { 2 - 4 } & 2 MST & 4 MST & 6 MST \\
\hline $\mathrm{K}_{1} \mathrm{Y}_{1}$ & $11,83 \mathrm{a}$ & $15,67 \mathrm{a}$ & $23,73 \mathrm{a}$ \\
$\mathrm{K}_{1} \mathrm{Y}_{2}$ & $14,17 \mathrm{~b}$ & $22,33 \mathrm{~b}$ & $25,20 \mathrm{a}$ \\
$\mathrm{K}_{1} \mathrm{Y}_{3}$ & $15,67 \mathrm{c}$ & $23,00 \mathrm{bc}$ & $33,53 \mathrm{~b}$ \\
$\mathrm{~K}_{2} \mathrm{Y}_{1}$ & $18,00 \mathrm{~d}$ & $23,73 \mathrm{~cd}$ & $35,50 \mathrm{~b}$ \\
$\mathrm{~K}_{2} \mathrm{Y}_{2}$ & $20,16 \mathrm{e}$ & $24,30 \mathrm{de}$ & $40,55 \mathrm{c}$ \\
$\mathrm{K}_{2} \mathrm{Y}_{3}$ & $21,17 \mathrm{ef}$ & $24,50 \mathrm{de}$ & $45,48 \mathrm{~d}$ \\
$\mathrm{~K}_{3} \mathrm{Y}_{1}$ & $21,70 \mathrm{f}$ & $24,70 \mathrm{de}$ & $48,16 \mathrm{f}$ \\
$\mathrm{K}_{3} \mathrm{Y}_{2}$ & $25,30 \mathrm{~g}$ & $36,70 \mathrm{f}$ & $60,83 \mathrm{~g}$ \\
$\mathrm{~K}_{3} \mathrm{Y}_{3}$ & $22,00 \mathrm{f}$ & $25,20 \mathrm{e}$ & $47,33 \mathrm{e}$ \\
\hline \multirow{2}{*}{ BNJ 5 \% } & 1,07 & 1,07 & 3,40 \\
\hline
\end{tabular}

Keterangan : Angka-angka yang didampingi huruf yang sama pada kolom yang sama tidak berbeda nyata pada uji BNJ taraf $5 \%$.

Pada Tabel 2 terlihat bahwa rata-rata tinggi tanaman tertinggi pada umur 2, 4 dan 6 MST dihasilkan oleh perlakuan interaksi pemberian pupuk kandang kotoran ayam dengan dosis 40 ton/ha dan pupuk NPK Mutiara Yaramila dengan dosis sebesar $300 \mathrm{~kg} / \mathrm{ha}\left(\mathrm{K}_{3} \mathrm{Y}_{2}\right)$ rata-rata setinggi $25,30 \mathrm{~cm}, 36,70 \mathrm{~cm}, 60,83 \mathrm{~cm}$ dan berbeda nyata terhadap semua perlakuan lainnya.

\section{Jumlah Daun}

Hasil analisis ragam menunjukkan bahwa interaksi perlakuan pemberian pupuk kandang kotoran ayam dan pupuk NPK Mutiara Yaramila berpengaruh sangat nyata terhadap parameter jumlah daun umur 2, 4 dan 6 MST. Hasil uji beda rata-ratanya disajikan pada Tabel 3.

Tabel 3. Hasil uji beda rata-rata Jumlah Daun

\begin{tabular}{|c|c|c|c|}
\hline \multirow{2}{*}{ Perlakuan } & \multicolumn{3}{|c|}{ Jumlah Daun } \\
\cline { 2 - 4 } & 2 MST & 4 MST & $\mathbf{6 ~ M S T}$ \\
\hline $\mathrm{K}_{1} \mathrm{Y}_{1}$ & $3,67 \mathrm{a}$ & $5,00 \mathrm{a}$ & $7,67 \mathrm{a}$ \\
$\mathrm{K}_{1} \mathrm{Y}_{2}$ & $4,00 \mathrm{a}$ & $5,67 \mathrm{ab}$ & $8,00 \mathrm{a}$ \\
$\mathrm{K}_{1} \mathrm{Y}_{3}$ & $4,67 \mathrm{abc}$ & $5,67 \mathrm{ab}$ & $9,67 \mathrm{ab}$ \\
$\mathrm{K}_{2} \mathrm{Y}_{1}$ & $5,00 \mathrm{abc}$ & $6,33 \mathrm{abc}$ & $10,00 \mathrm{ab}$ \\
$\mathrm{K}_{2} \mathrm{Y}_{2}$ & $5,33 \mathrm{abc}$ & $7,00 \mathrm{bcd}$ & $11,67 \mathrm{bc}$ \\
$\mathrm{K}_{2} \mathrm{Y}_{3}$ & $6,00 \mathrm{bc}$ & $7,33 \mathrm{~cd}$ & $12,67 \mathrm{c}$ \\
$\mathrm{K}_{3} \mathrm{Y}_{1}$ & $6,67 \mathrm{c}$ & $7,66 \mathrm{~cd}$ & $18,67 \mathrm{~d}$ \\
$\mathrm{~K}_{3} \mathrm{Y}_{2}$ & $8,67 \mathrm{~d}$ & $11,00 \mathrm{e}$ & $23,33 \mathrm{e}$ \\
$\mathrm{K}_{3} \mathrm{Y}_{3}$ & $6,33 \mathrm{bc}$ & $8,00 \mathrm{~d}$ & $20,00 \mathrm{~d}$ \\
\hline \multirow{2}{*}{$\mathrm{BNJ} 5 \%$} & 1,90 & 1,57 & 2,34 \\
\hline Keterangan & \multicolumn{4}{|c|}{ Angka-angka yang didampingi } \\
\multicolumn{4}{|c|}{ huruf yang sama sama pada kolom } \\
yada uji BNJ taraf $5 \%$
\end{tabular}

Pada Tabel 3 terlihat bahwa rata-rata jumlah daun terbanyak pada umur 2, 4 dan 6 MST dihasilkan oleh perlakuan interaksi pemberian pupuk kandang kotoran ayam dengan dosis 40 ton/ha dan pupuk NPK Mutiara Yaramila dengan dosis sebesar $300 \mathrm{~kg} / \mathrm{ha}\left(\mathrm{K}_{3} \mathrm{Y}_{2}\right)$ yaitu rata-rata sebanyak 8,67 helai, 11,00 helai, 23,33 helai dan berbeda nyata terhadap semua perlakuan lainnya. 


\section{Jumlah Cabang Produktif}

Hasil analisis ragamnya menunjukkan bahwa interaksi perlakuan pemberian pupuk kandang kotoran ayam dan pupuk NPK Mutiara Yaramila berpengaruh sangat nyata terhadap parameter jumlah cabang. Hasil uji beda rata-rata jumlah cabang disajikan pada Tabel 4.

Tabel 4. Hasil uji beda rata-rata Jumlah Cabang Produktif

\begin{tabular}{|c|c|}
\hline Perlakuan & Jumlah Cabang Produktif \\
\hline $\mathrm{K}_{1} \mathrm{Y}_{1}$ & $2,33 \mathrm{a}$ \\
$\mathrm{K}_{1} \mathrm{Y}_{2}$ & $2,33 \mathrm{a}$ \\
$\mathrm{K}_{1} \mathrm{Y}_{3}$ & $3,33 \mathrm{ab}$ \\
$\mathrm{K}_{2} \mathrm{Y}_{1}$ & $4,00 \mathrm{bc}$ \\
$\mathrm{K}_{2} \mathrm{Y}_{2}$ & $5,33 \mathrm{~cd}$ \\
$\mathrm{~K}_{2} \mathrm{Y}_{3}$ & $7,00 \mathrm{e}$ \\
$\mathrm{K}_{3} \mathrm{Y}_{1}$ & $8,67 \mathrm{f}$ \\
$\mathrm{K}_{3} \mathrm{Y}_{2}$ & $6,00 \mathrm{de}$ \\
$\mathrm{K}_{3} \mathrm{Y}_{3}$ & 1,34 \\
\hline BNJ $5 \%$ & \\
\hline
\end{tabular}

Keterangan: Angka-angka yang didampingi huruf yang sama pada kolom yang sama tidak berbeda nyata pada uji BNJ taraf $5 \%$.

Pada Tabel 4 terlihat bahwa rata-rata jumlah cabang terbanyak dihasilkan oleh perlakuan interaksi pemberian pupuk kandang kotoran ayam dengan dosis 40 ton/ha dan pupuk NPK Mutiara Yaramila dengan dosis $300 \mathrm{~kg} / \mathrm{ha}$ $\left(\mathrm{K}_{3} \mathrm{Y}_{2}\right)$ dengan rata-rata sebanyak 8,67 cabang dan berbeda nyata terhadap semua perlakuan lainnya.

\section{Jumlah Buah dan Berat Buah}

Hasil analisis ragam menunjukkan bahwa interaksi perlakuan pemberian pupuk kandang kotoran ayam dan pupuk NPK Mutiara Yaramila berpengaruh sangat nyata terhadap parameter jumlah buah dang berat buah per tanaman. Hasil uji beda rata-rata untuk kedua parameter tersebut disajikan pada Tabel 5.

Tabel 5. Hasil uji beda rata-rata Jumlah Buah dan Berat Buah Per Tanaman (gram)

\begin{tabular}{|c|c|c|}
\hline Perlakuan & Jumlah Buah & Berat Buah \\
\hline $\mathrm{K}_{1} \mathrm{Y}_{1}$ & $1,33 \mathrm{a}$ & $129,50 \mathrm{a}$ \\
$\mathrm{K}_{1} \mathrm{Y}_{2}$ & $1,67 \mathrm{ab}$ & $134,67 \mathrm{a}$ \\
$\mathrm{K}_{1} \mathrm{Y}_{3}$ & $2,00 \mathrm{ab}$ & $143,57 \mathrm{a}$ \\
$\mathrm{K}_{2} \mathrm{Y}_{1}$ & $2,00 \mathrm{ab}$ & $144,43 \mathrm{a}$ \\
$\mathrm{K}_{2} \mathrm{Y}_{2}$ & $2,33 \mathrm{ab}$ & $165,33 \mathrm{ab}$ \\
$\mathrm{K}_{2} \mathrm{Y}_{3}$ & $2,33 \mathrm{ab}$ & $170,07 \mathrm{ab}$ \\
$\mathrm{K}_{3} \mathrm{Y}_{1}$ & $3,00 \mathrm{bc}$ & $234,83 \mathrm{~b}$ \\
$\mathrm{~K}_{3} \mathrm{Y}_{2}$ & $4,33 \mathrm{c}$ & $417,23 \mathrm{c}$ \\
$\mathrm{K}_{3} \mathrm{Y}_{3}$ & $2,33 \mathrm{ab}$ & $170,00 \mathrm{ab}$ \\
\hline BNJ 5 \% & 1,34 & 77,66 \\
\hline \multicolumn{3}{|c|}{ Keterangan : Angka-angka yang didampingi } \\
\multicolumn{3}{|c|}{ huruf yang sama pada kolom yang } \\
\multicolumn{3}{|c|}{ BNJ taraf 5\%. }
\end{tabular}

Pada Tabel 5 terlihat bahwa rata-rata jumlah buah terbanyak dan berat buah terbesar dihasilkan oleh perlakuan interaksi pemberian pupuk kandang kotoran ayam dengan dosis 40 ton/ha dan pupuk NPK Mutiara Yaramila dengan dosis $300 \mathrm{~kg} / \mathrm{ha}\left(\mathrm{K}_{3} \mathrm{Y}_{2}\right)$ dengan rata-rata 4,33 buah dan berat 417,23 gram.

Untuk parameter jumlah buah per tanaman, perlakuan pemberian pupuk kandang kotoran ayam sebesar 40 ton/ha dan pupuk NPK Mutiara Yaramila sebesar $300 \mathrm{~kg} / \mathrm{ha}\left(\mathrm{K}_{3} \mathrm{Y}_{2}\right)$ tidak berbeda nyata hanya dengan perlakuan $\mathrm{K}_{3} \mathrm{Y}_{3}$ (pemberian pupuk kandang kotoran ayam sebesar 40 ton/ha dan pupuk NPK Mutiara Yaramila sebesar 400 $\mathrm{kg} / \mathrm{ha}$ ). Sedangkan untuk parameter berat buah per tanaman, perlakuan $K_{3} Y_{2}$ berbeda nyata terhadap semua perlakuan lainnya. 


\section{Pembahasan}

Berdasarkan hasil pengamatan terhadap parameter pertumbuhan dan hasil tanaman yang meliputi: tinggi tanaman, jumlah daun, jumlah cabang produktif, jumlah buah dan berat buah per tanaman, perlakuan interaksi pemberian pupuk kandang kotoran ayam dan pupuk NPK Mutiara Yaramila menunjukkan pengaruh yang sangat nyata. Hal ini disebabkan karena pemberian kedua pupuk tersebut secara bersama-sama mampu menambah ketersediaan unsur hara di dalam tanah dan menunjang pertumbuhan vegetatif dang generatif tanaman. Karena seperti diketahui unsur hara dalam tanah berpasir sangat rendah, karena mempunyai porositas sangat tinggi menyebabkan unsur hara yang ada mudah hilang dan larut dalam peresapan tanah sehingga tidak dapat diserap oleh tanaman secara sempurna.

Ketersediaan unsur hara akan sangat berpengaruh terhadap pertumbuhan tanaman, baik tinggi tanaman, jumlah daun, jumlah cabang, jumlah buah dan berat buah per tanaman. Keadaan demikian tidak terlepas dari banyaknya unsur hara yang dapat diserap oleh akar tanaman dari dalam tanah (Agustina, 1990).

Hampir setiap tanaman untuk memperoleh hasil yang optimal menghendaki kondisi tanah sebagai media tumbuhnya memiliki sifat fisik, kimia dan biologi yang baik. Oleh karena itu setiap upaya untuk meningkatkan hasil pertanian dengan meningkatkan produktivitas tanah harus diarahkan kepada peningkatan ketiga aspek, yaitu suplai bahan-bahan yang bersifat menambahkan unsur hara sekaligus yang dapat menahan larutnya unsur hara di dalam tanah, $\mathrm{pH}$ tanah dan suplai air (Agustina, 1990).
Lebih baiknya perlakuan interaksi pemberian pupuk kandang kotoran ayam dengan dosis 40 ton/ha dan pupuk NPK Mutiara Yaramila dengan dosis $300 \mathrm{~kg} / \mathrm{ha}\left(\mathrm{K}_{3} \mathrm{Y}_{2}\right)$ yang diberikan pada media tanah berpasir sangat mempengaruhi pertumbuhan tanaman, hal ini terbukti untuk parameter tinggi tanaman umur 2, 4 dan 6 MST $(25,30 \mathrm{~cm}, 36,37 \mathrm{~cm}$ dan $60,83 \mathrm{~cm})$, jumlah daun umur 2, 4 dan 6 MST (8,67 helai, 11,00 helai dan 23,33 helai) dan jumlah cabang produktif $(8,67$ cabang) lebih tinggi dibandingkan parameter perlakuan lainnya.

Meningkatnya parameter pertumbuhan seperti perlakuan tersebut diatas, hal ini membuktikan bahwa kedua perlakuan tersebut secara bersama-sama mampu memacu pertumbuhan vegetatif tanaman secara optimal. Karena seperti diketahui pupuk kandang kotoran ayam dan pupuk NPK Mutiara Yaramila secara bersama-sama dapat memperbaiki sifat fisik, kimia dan biologi tanah, seperti menambah unsur hara dalam tanah, memperbaiki struktur tanah, meningkatkan daya menahan air serta dapat merangsang perkembangan dan aktivitas jasad renik dalam tanah. Hal ini disebabkan karena pemberian kedua pupuk tersebut dapat meningkatkan $\mathrm{pH}$ tanah dan meningkatkan ketersediaan unsur hara $\mathrm{N}, \mathrm{P}, \mathrm{K}, \mathrm{Ca}$ dan $\mathrm{Mg}$ (Lingga, 2000).

Peningkatan pertumbuhan vegetatif pada parameter tinggi tanaman, jumlah daun dan jumlah cabang produktif sangat dipengaruhi oleh adanya peranan unsur hara seperti $\mathrm{N}, \mathrm{P}$ dan $\mathrm{K}$. Lingga dan Marsono (2001) menjelaskan bahwa peranan nitrogen bagi tanaman adalah untuk merangsang pertumbuhan secara keseluruhan, khususnya cabang, batang dan daun. Nitrogen 
berfungsi sebagai pembentuk klorofil, protein dan lemak. Nitrogen juga sebagai penyusun enzim yang terdapat dalam sel, sehingga mempengaruhi pertumbuhan karbohidrat yang sangat berperan dalam pertumbuhan tanaman (Lingga, 2000). Sosrosoedirdjo (2004) menambahkan bahwa karbohidrat merupakan bahan yang sangat diperlukan dalam pembelahan sel, perpanjangan sel, pembesaran sel dan pembentukkan jaringan untuk perkembangan batang, daun dan akar. Fosfor berfungsi mengatasi pengaruh negatif dari nitrogen, memperbaiki perkembangan akar dan memperbaiki kualitas hasil. Kemudian $\mathrm{K}$ berfungsi dalam mengatur keseimbangan Nitrogen dan Fosfor.

Terjadinya peningkatan pertumbuhan yang optimal pada fase vegetatif akan terus berlanjut pada peningkatan hasil tanaman sampai fase generatif. Ini ditunjukkan oleh meningkatnya jumlah buah dan berat buah yang rata-rata sebesar 4,33 buah dan 417,23 gram pada perlakuan pemberian pupuk kandang kotoran ayam sebesar 40 ton/ha dengan pupuk NPK Mutiara Yaramila sebesar $300 \mathrm{~kg} / \mathrm{ha}\left(\mathrm{K}_{3} \mathrm{Y}_{2}\right)$.

Pada saat pertumbuhan dan perkembangan tanaman sampai tanaman menghasilkan dibutuhkan unsur hara dalam jumlah yang cukup, khususnya unsur fosfor $(P)$ dan kalium (K). Kandungan unsur $\mathrm{P}$ dan $\mathrm{K}$ pada pupuk kandang kotoran ayam dan pupuk NPK Mutiara Yaramila cukup tinggi (16\%), diduga pemberian NPK Mutiara Yaramila dapat memenuhi kebutuhan hara $\mathrm{P}$ dan $\mathrm{K}$ untuk tanaman terong sehingga pada saat panen dapat menghasilkan jumlah buah dan berat buah yang lebih baik. Lingga (2000), mengemukakan bahwa pengaruh fosfor $(P)$ dapat meningkatkan hasil tanaman, perbaikkan kualitas hasil dan mempercepat pematangan, sedangkan kalium (K) berperan sebagai katalisator berbagai reaksi enzimatik dan proses fisiologi lainnya sehingga secara keseluruhan berpengaruh terhadap pertumbuhan dan kualitas hasil.

Terjadinya penurunan pada parameter pertumbuhan dan hasil tanaman seperti tinggi tanaman, jumlah daun, jumlah cabang produktif, jumlah buah dan berat buah per tanaman pada perlakuan interaksi pemberian pupuk kandang kotoran ayam sebesar 40 ton/ha dengan pupuk NPK Mutiara Yaramila sebesar $400 \mathrm{~kg} / \mathrm{ha}\left(\mathrm{K}_{3} \mathrm{Y}_{3}\right)$ hal ini disebabkan karena ketersediaan unsur nitrogen pada kedua kombinasi pupuk tersebut berlebihan. Karena seperti diketahui kandungan unsur nitrogen yang berlebihan atau sangat tinggi di dalam tanah akan menjadi faktor pembatas bagi penyerapan unsur P dan K. Yutono (2000), menyatakan bahwa kadar nitrogen tertentu akan meningkatkan pertumbuhan tanaman dan fiksasi $\mathrm{N}_{2}$, tetapi pada kadar yang lebih tinggi pengaruhnya terhadap pertumbuhan akan berkurang dann akan mengurangi jumlah $\mathrm{N}_{2}$ yang difiksasi.

\section{KESIMPULAN DAN SARAN \\ Kesimpulan}

Hasil analisis ragam menunjukkan bahwa perlakuan interaksi pemberian pupuk kandang kotoran ayam dan pupuk NPK Mutiara Yaramila berpengaruh sangat nyata terhadap parameter tinggi tanaman, jumlah daun, jumlah cabang produktif, jumlah buah per tanaman dan berat buah per tanaman. 
Pemberian pupuk kandang kotoran ayam dengan dosis 40 ton/ha dan pupuk NPK Mutiara Yaramila sebesar $300 \mathrm{~kg} / \mathrm{ha}\left(\mathrm{K}_{3} \mathrm{Y}_{2}\right)$ memberikan hasil tertinggi untuk parameter tinggi tanaman umur 2, 4 dan 6 MST $(25,30 \mathrm{~cm}, 36,37 \mathrm{~cm}$ dan $60,83 \mathrm{~cm})$, jumlah daun umur 2, 4 dan 6 MST ( 8,67 helai, 11,00 helai dan 23,33 helai), jumlah cabang ( 8,67 buah), jumlah buah (4,33 buah) dan berat buah $(417,23 \mathrm{gram})$.

\section{Saran}

Untuk pembudidayaan tanaman terong pada tanah berpasir disarankan untuk menggunakan pemakaian pupuk kandang kotoran ayam dengan dosis 40 ton/ha dan pupuk NPK Mutiara Yaramila dengan dosis $300 \mathrm{~kg} / \mathrm{ha}$.

\section{DAFTAR PUSTAKA}

Anonim, 1979. Pedoman Bercocok Tanam Hortikultura. Direktorat Jendral Pertanian Tanaman Pangan, Jakarta.

Anonim, 2000. Laporan Tahunan Dinas Pertanian Kalimantan Tengah. Palangkaraya.

Agustina, 1990. Nutrisi Tanaman. Renika cipta. Jakarta.

Hakim, N. Dkk. 1986. Dasar-Dasar IImu Tanah. Universitas Lampung. Lampung.

Lingga, P. 2000. Petunjuk Penggunaan Pupuk. Penebar Swadaya. Jakarta.

Lingga, P. dan Marsono. 2001. Petunjuk Penggunaan Pupuk. Penebar Swadaya. Jakarta.

Nyakpa, M.Y. A.M. Lubis, M.A. Pulung, A.G. Amrah, A. Munawar, G.B. Hong, dan N. Hakim. 1988. Kesuburan Tanah. Penerbit Universitas Lampung. Lampung.
Pairunan, et al., 1995. Anna. Y.J.L, Manate, Arifin, Selo S.R.S Amosir, Romuados Tangkai Sari, J.R. Lolapau Mace Bachrul Ibrahim, Haji Adji Asmadi. 1995. Dasar-dasar IImu Tanah. Badan Kerjasama Perguruan Tinggi Indonesia Bagian Timur.

Rukmana, 2000. Bertanam Terung. Kanisius. Yogyakarta. 56 hal

Rosmarkam, A dan N.W. Yuwono. 2000. IImu Kesuburan Tanah. Kanisius. Yogyakarta.

Rubiyo, 2006. Pengaruh Pemberian Pupuk Kandang Kotoran Ayam Dan Pupuk Majemuk NPK Tora Terhadap Pertumbuhan Nilam Pada Tanah Berpasir. Skripsi. Faperta UMP.

Samadi, B. 2001. Budidaya Terung Hibrida. Kanisius. Yogyakarta. 67 hal.

Sarief, Saifudin. Kesuburan Tanah dan dan Pemupukan Tanah Pertanian. Pustaka Buana. Bandung, 66 hal

Sarwono, H. 1992. Ilmu Tanah. Mediatama Sarana Perkasa. Jakarta.

Soetasad, A. 1999. Budidaya Terung Lokal dan Terung Jepang. Penebar Swadaya. Jakarta

Sutedjo. 2000. Pupuk Dan Cara Pemupukan. Bina Aksara. Jakarta.

Sosrosoedjirdjo, 2004. IImu Memupuk. Jilid I. CV. Yasaguna. Jakarta.

Yutono. 2000. Inokulasi Rhizobium Pada Kedelai. Pusat Penelitian dan Pengembangan Tanaman Pangan. Bogor.

(http://id.aswers.yahoo.com/question/indexqid=20 0817212348AARw3V.Internet) 